\title{
THE TECHNOLOGICAL INVESTIGATIONS OF MANUFACTURING OF ENERGY CHIPS
}

\author{
Ziedonis Miklašēvičs \\ Rēzeknes Augstskola \\ Atbrīvošanas aleja 90, Rēzekne, LV 4601 \\ E-mail: Z.Miklasevics@1vm.lv, tālr.26473397
}

\begin{abstract}
The methodology in Latvia forest industry provide to determine the quality of energy chips only in long-term storage places before selling. Due to the lack of hard empirical data about the quality parameters of energy chips in different phases of manufacturing process, this research paper consists of:

- $\quad$ the identification and analyses of the factors that influenced the values of energy chips quality features such as: bulk density, moisture content, ash content, higher and lower heating value according to actual moisture content and per dry mass of the chips;

- the methodology for determination the quality parameters of energy chips by analysis the wood moisture content and by choice the method of the manufacturing of energy chips.
\end{abstract}

Keywords: energy chips; technological investigations.

\section{Ievads}

The manufacturing of energy chips and transportation of assortiments to storage-s or to consumers is the process which includes the sequent technological phases: the choose of harvesting sites where the harvesting residues are planned to manufacture in energy chips $[10,11,12]$, collection and storage of the harvesting residues in harvesting sites, chipping, loading, transportation, unloading and storage of energy chips.

To control the quality of energy chips and to manage the technological process of manufacturing, it is necessary to determine the moisture content of energy chips, ash content, bulk density and others factors that influenced the results in the controll points of the technological process.

Depends of dominant tree specie-s and forest types, the harvesting residues in harvesting sites mainly consists of branches and tree tops. The amount of the harvesting residues used in manufacturing of energy chips in deciduous forest stands reach $29 \%$ of amount of the round wood assortiments, in spruce forest stands $26 \%$, in pine forest stands $14 \%[7,8,10]$.

At particular moisture content of energy chips the bulk density depends of the factors such as: branches, needles, bark, stem wood, heartwood and sapwood proportion in harvesting residues, the thickness of annual rings etc.

For the same tree species the bulk density could be with more or less deviation according to wood moisture content, forest type, forest stand age class, etc. For example, the bulk density of the alder wood $(\mathrm{W}=0 \%)$ in rich deciduous forest type is $450 \mathrm{~kg} / \mathrm{m}$ in wet deciduous forest type $-440 \mathrm{~kg} / \mathrm{m}^{3}[2]$.

The methodology used in Latvia forest branch which determines the quality of energy chips only at the delivery places or storage places when loading of the ships are being, not providing the objective information about quality parameters of the delivered single loads.

As the result, the quality parameters of the energy chips loads could be reduced because of long -term storing. The quality of energy chips is dependent upon the source of the biomass and the techniques employed for comminution, handling and storage Chemical and biochemical reactions take place during the storage of chips. The reactions cause loss of dry 
matter, formation of fines, an increase in ash content, and a decrease of volatile materials. It was concluded that long-term storage of energy chips should be avoided $[4,5,8,9]$.

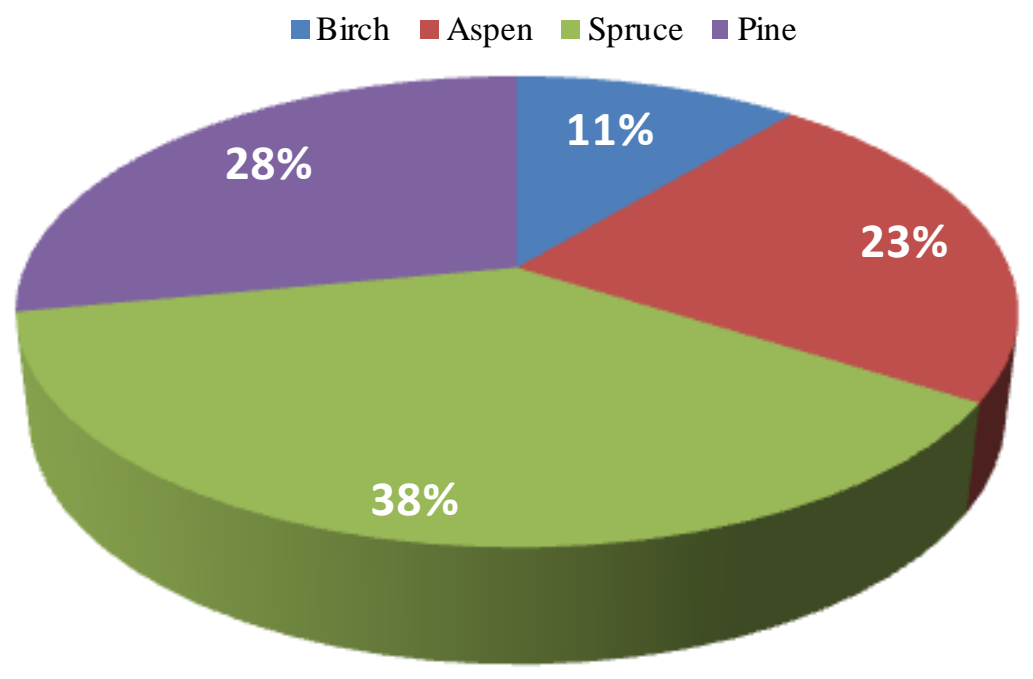

Fig. 1. Dominant tree species in energy chips manufacturing places in 2010

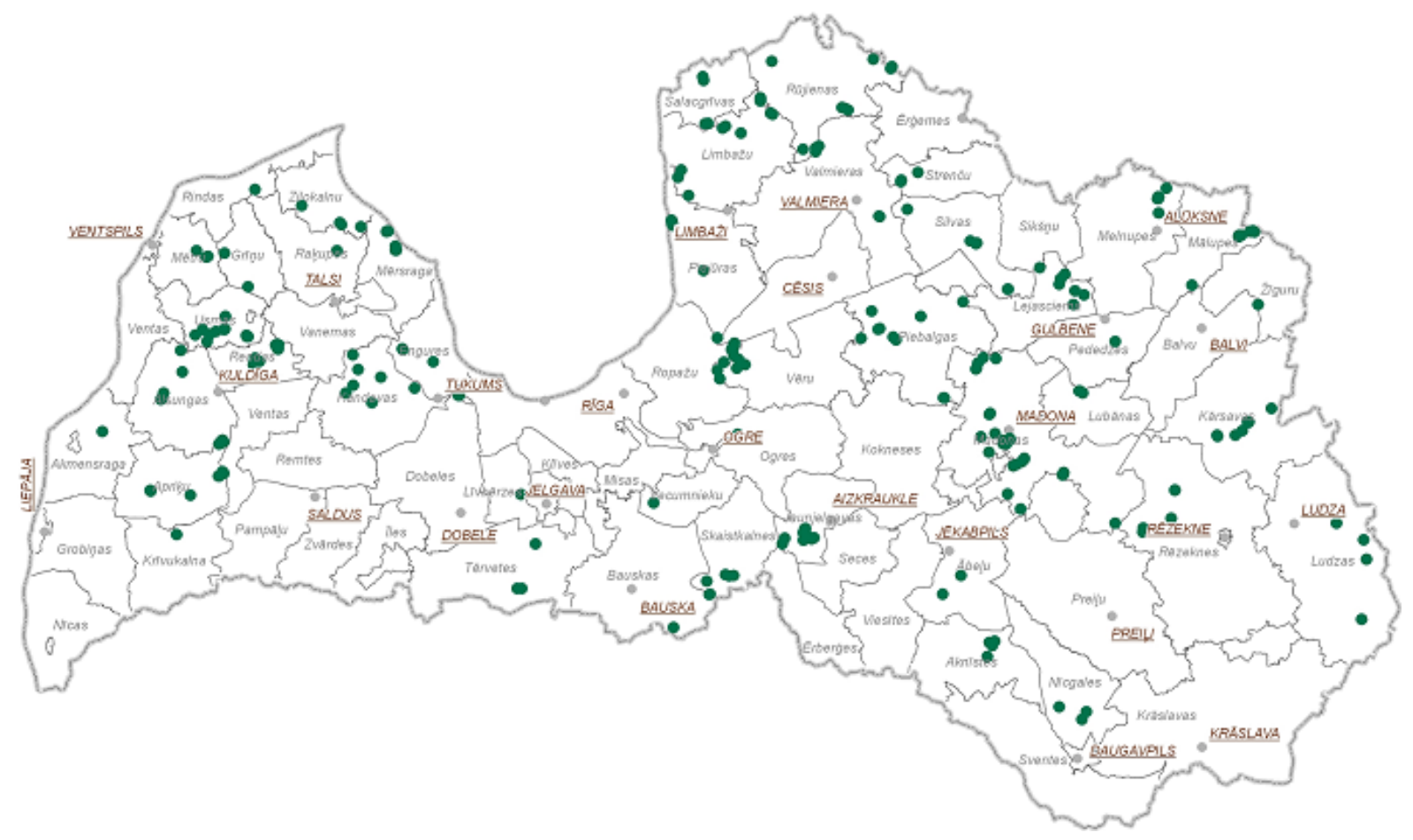

Fig. 2. Dominant energy chips manufacturing places in 2010

For objective assessment of the quality parameters of energy chips, adequate tasks have been handled:

1. to investigate the quality parameters of energy chips according to laboratory analyses according to standards: LVS CEN/TS 144774-2 (moisture content), LVS CEN/TS 14775 (ash content) un LVS CEN/TS 14918 (heating value) un LVS CEN/TS 15103 (bulk density) in the long -term energy chips storages for the period 01.2010. - 02.2011; 
2. to investigate the quality parameters of moisture content of sample portions of energy chips in fixed long-term storage-s (longer 2 months) according to standard LVS CEN/TS 14778-2:2005 (sampling) and to determine the moisture zones (fig.10) at a cross section of a chip's pile;

3. unintentionally, in determined months, in different Latvia regions, in different forest types which is represented by single tree specie (for example in pine-spruce forest (formula:10 spruce)) to perform the chipping of the harvesting residues in harvesting sites 2-4 weeks after logging and to determine the quality of energy chips by testing of the samples according to standards: LVS CEN/TS 144774-2 (moisture content), LVS CEN/TS 14775 (ash content) un LVS CEN/TS 14918 (heating value) un LVS CEN/TS 15103 (bulk density) for the period 01.2010.- 02.2011. To compare the obtaining results to:

3.1. the quality of the energy chips manufactured of the harvesting residues in the appropriate harvesting sites of forest types and wood species and stored in longterm storages( longer 6 months) for the corresponding period;

3.2. the quality of energy chips stored in long-term storages( longer 2 months) for the corresponding period.

4. to perform the analysis of correlation of the factors: moisture content, bulk density, ash content and heating values of energy chips.

\section{The methods and materials}

1. To achieve the objective, the analitical and experimental investigation have been performing based on technological process(2) (fig.3.) splitting it in main control points.

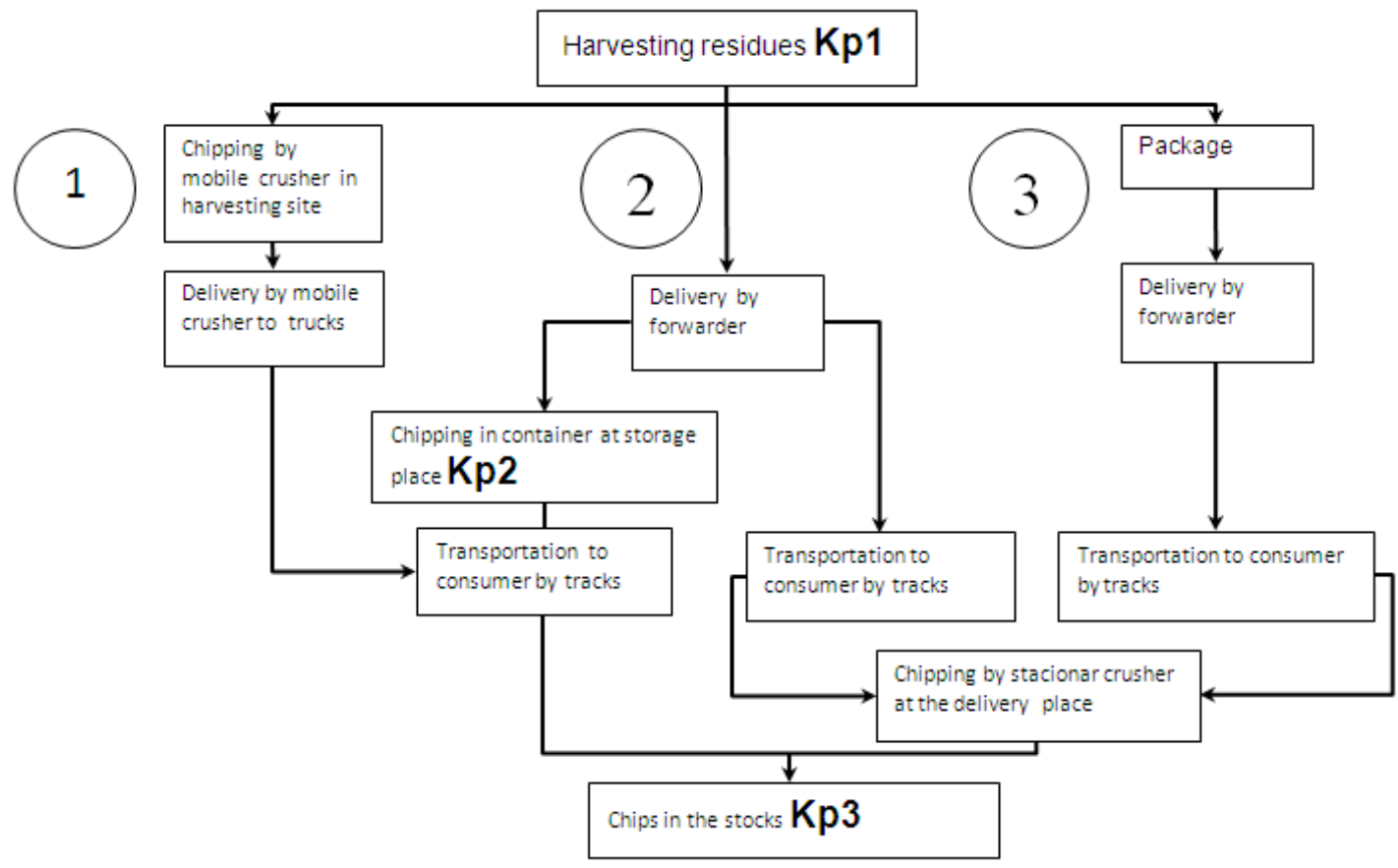

Fig. 3. The scheme of the possible technological process of manufacturing of energy chips

$\mathbf{1 , 2 , 3}$ - the technological process; Kp1, Kp2, Kp3 - the control points in the technological process for the energy chips quality control

2. Energy chips samples were taken in the control points of the technological process for investigation of the quality parameters according to standarts $[13,14,15,16,17,18]$. 


\section{The results}

1. The average parameters of energy chips bulk density have been determined 420$470 \mathrm{~kg} / \mathrm{m}^{3}$ by wood moisture content $(\mathrm{W}=0 \%$ ) (fig.4.).

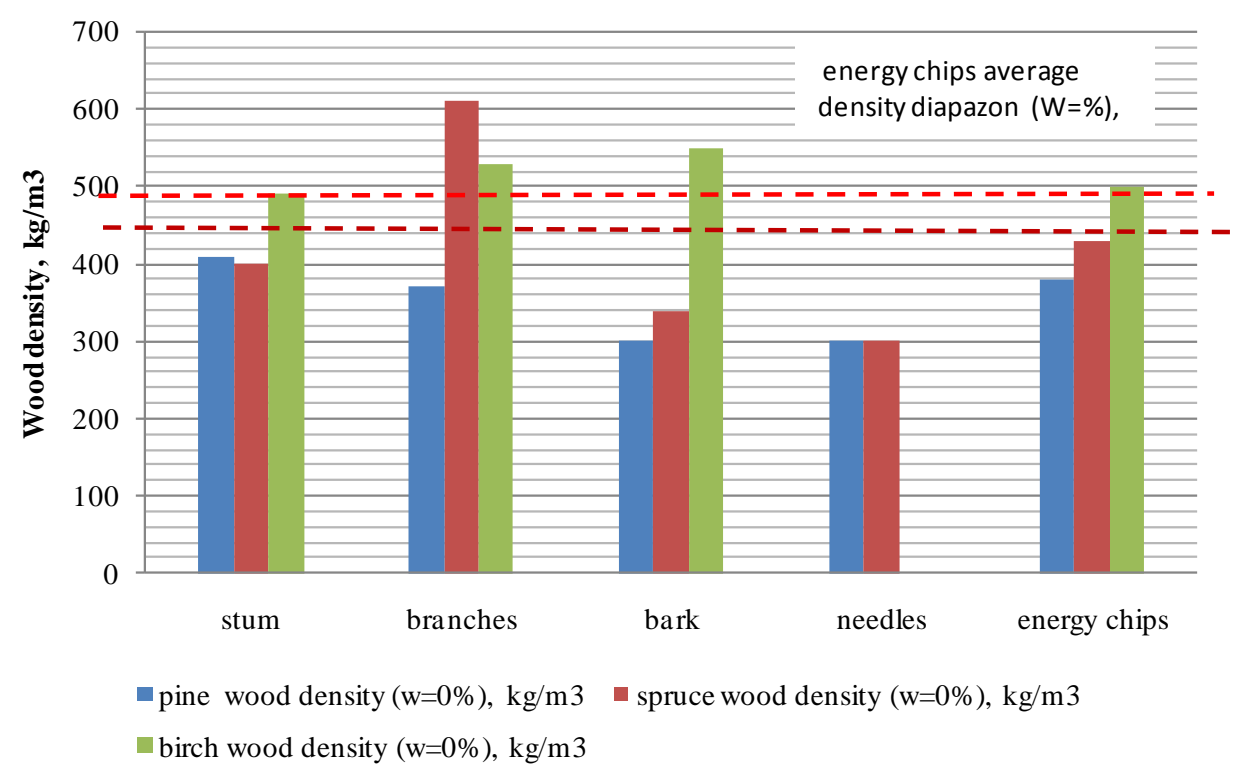

Fig. 4. The average bulk density of energy chips and different parts of the tree

2. Natural drying cannot bring the relative moisture content much more than $10 \%$ below the original [12]. It is practically impossible to decrease the relative moisture content of harvesting residues bellow $30 \%$ (fig.5.).

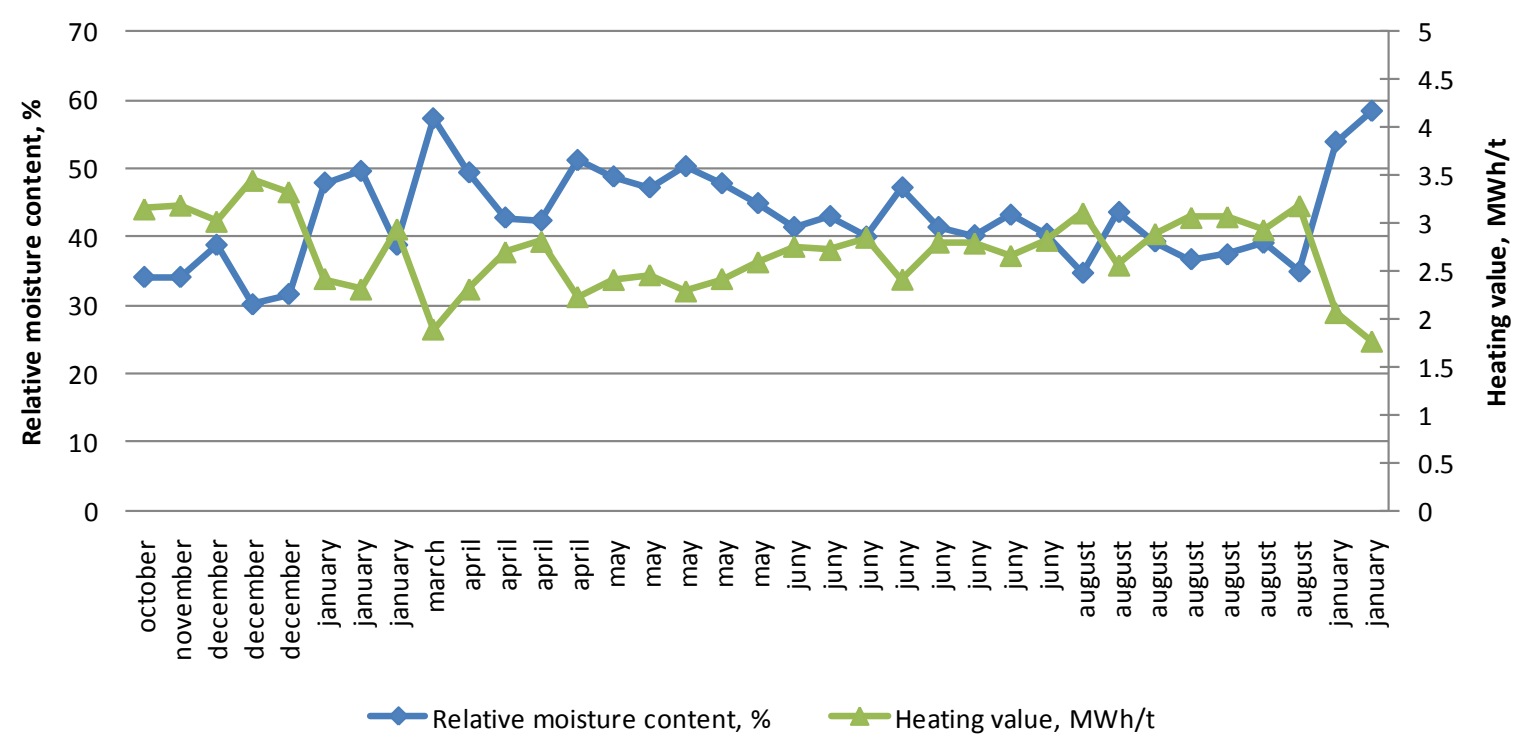

Fig. 5. The dynamic of the relative moisture content and heating value parameters of energy chips for the period 2009-2010

3. It is not advised to store the harvesting residues in athmosphere stocks for the period June-August. The optimal time for chipping is 2-4 weeks after logging when the moisture content of fresh wood (generally about 60\%) is reduced till 30-35\% (fig.6.). Prolonging the duration of the storage does not appear to have a positive effect.

By keeping harvesting residues in atmosphere stocks for prolonged term the relative moisture content in wood is increased, for example, in residues of some species like 
spruce sapwood roti s created which aggravates parameters of heating value (fig.7.), but the number of measurements is unsufficient to make a general conclusion regarding impact wood fault on energy chops quality.

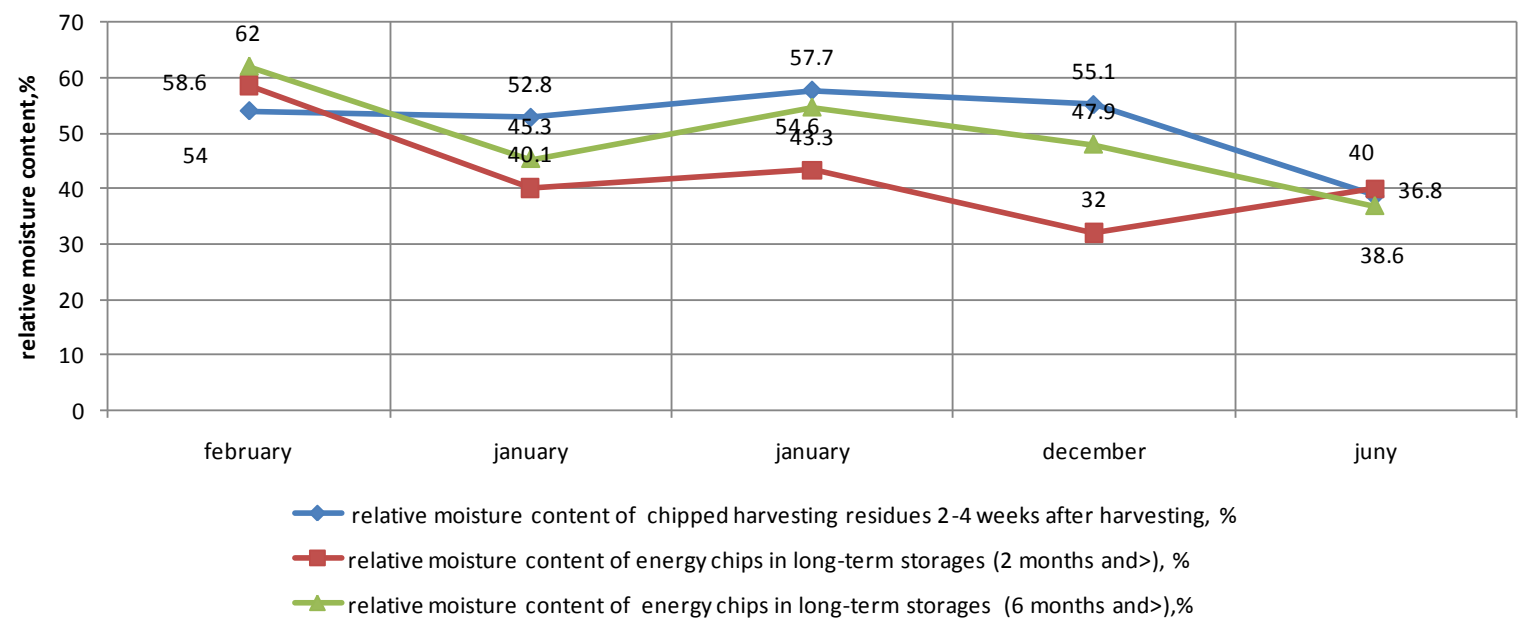

Fig. 6. The selected technological process impact on relative moisture content of energy chips

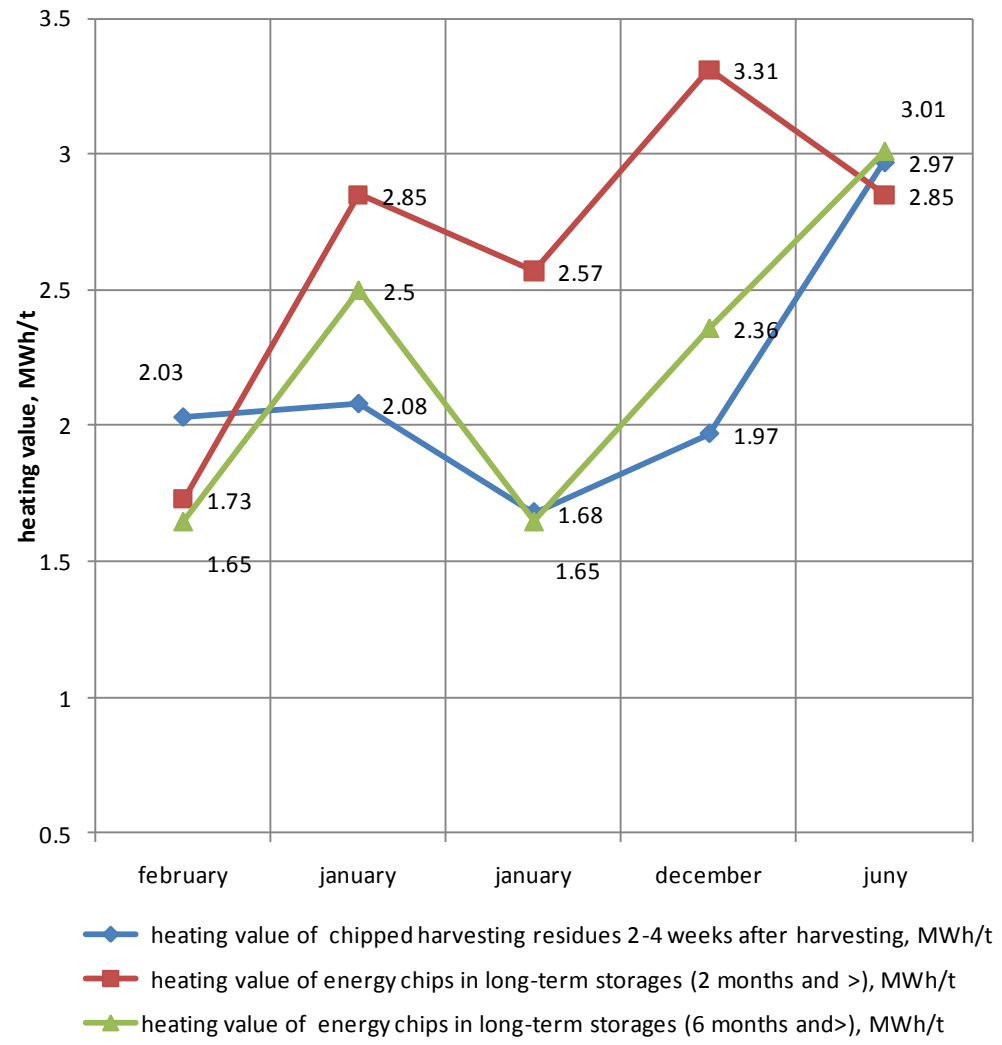

Fig. 7. The selected technological process impact on heating value of energy chips

4. The average relative wood moisture content of energy chips (42\%) (fig.8.) and ash content (3.8\%) (fig.9.) have been determined. 


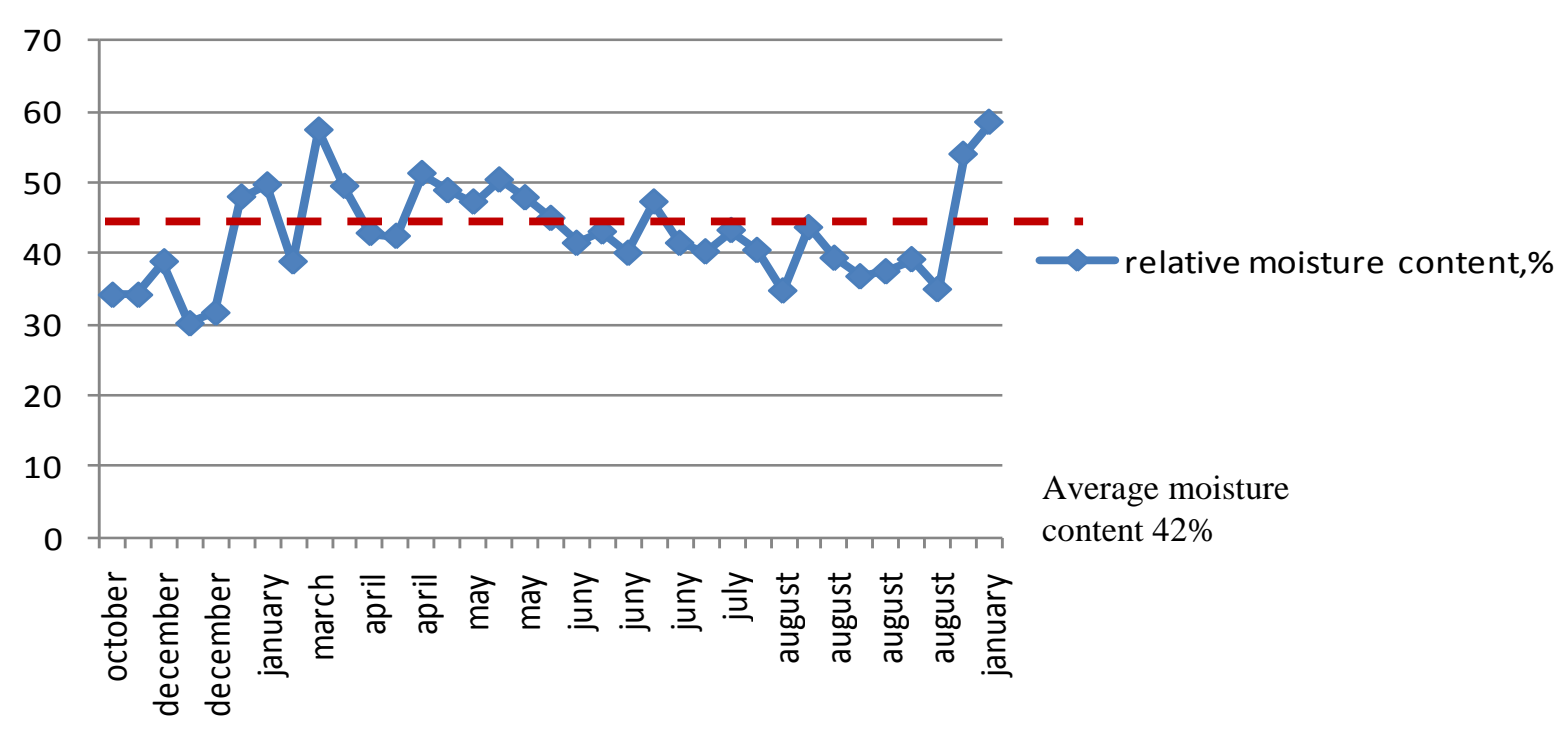

Fig. 8. The dynamic of wood moisture content

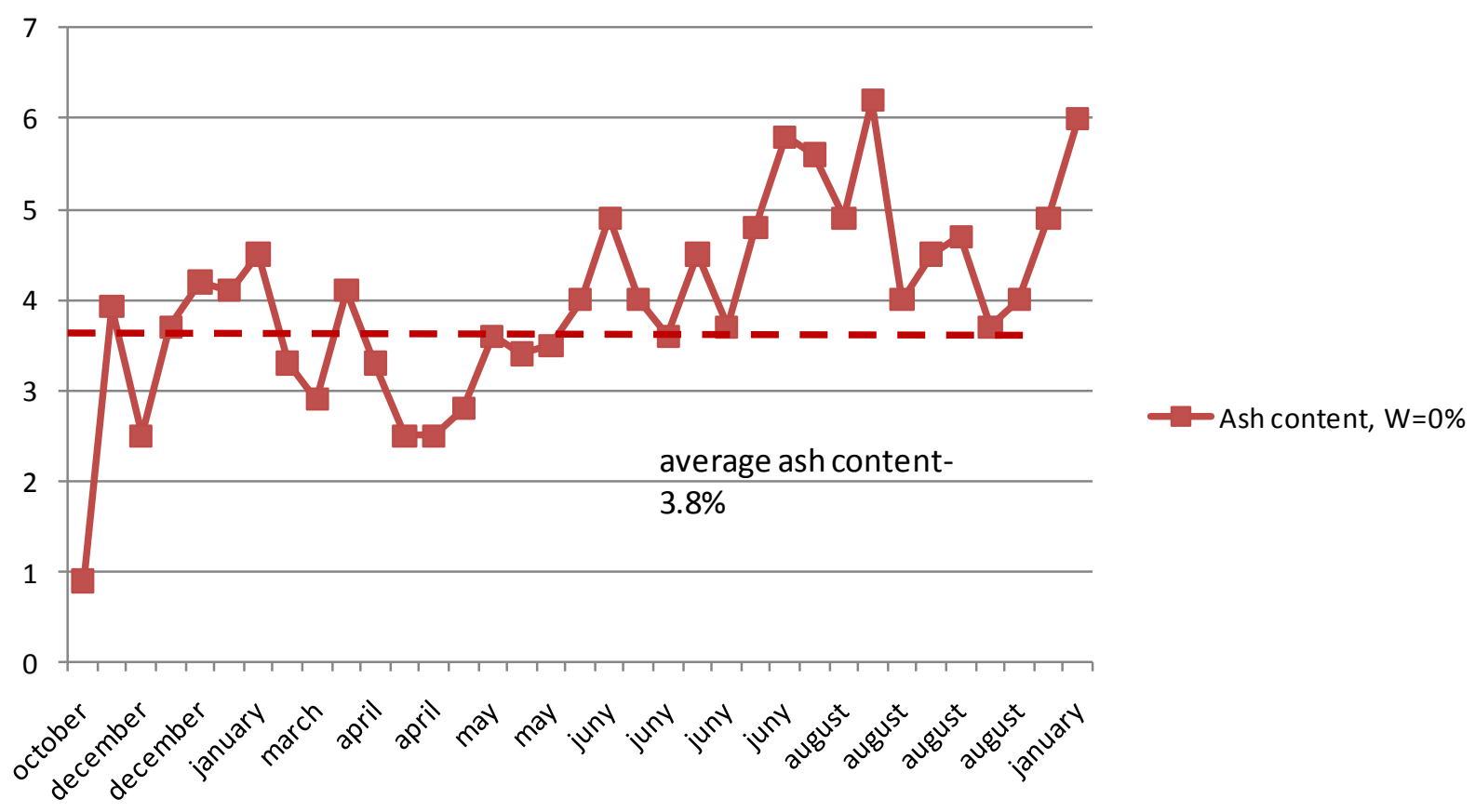

Fig. 9. The dynamic of ash content

5. The moisture zones and the wood relative moisture content in sampling places have been determinated in long-term energy chips storages (fig. 10.). 


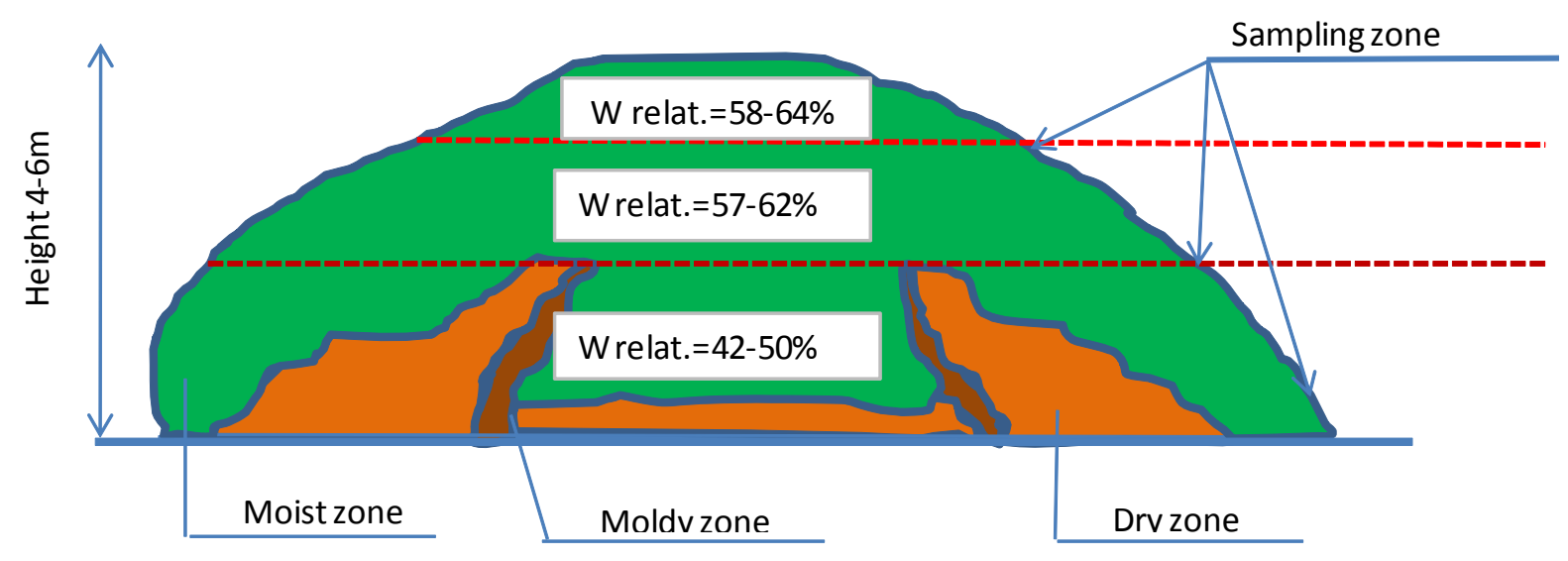

Fig. 10. Moisture zones and relative wood moisture content in sampling places at a cross section of a energy chips pile (storing 10.2010-01.2011.; average moisture content $58.4 \%$; amount $5003.71 \mathrm{~m}^{3}$ or 1696.44 t)

6. The heating value changes of energy chips in $99.1 \%$ cases can be explained by linear model of regression where the factor $\mathrm{X}$ - relative moisture content, $\%$. The model of regression $\mathrm{Y}=-0.0573 \mathrm{X}+5.1568$ (fig. 11.).

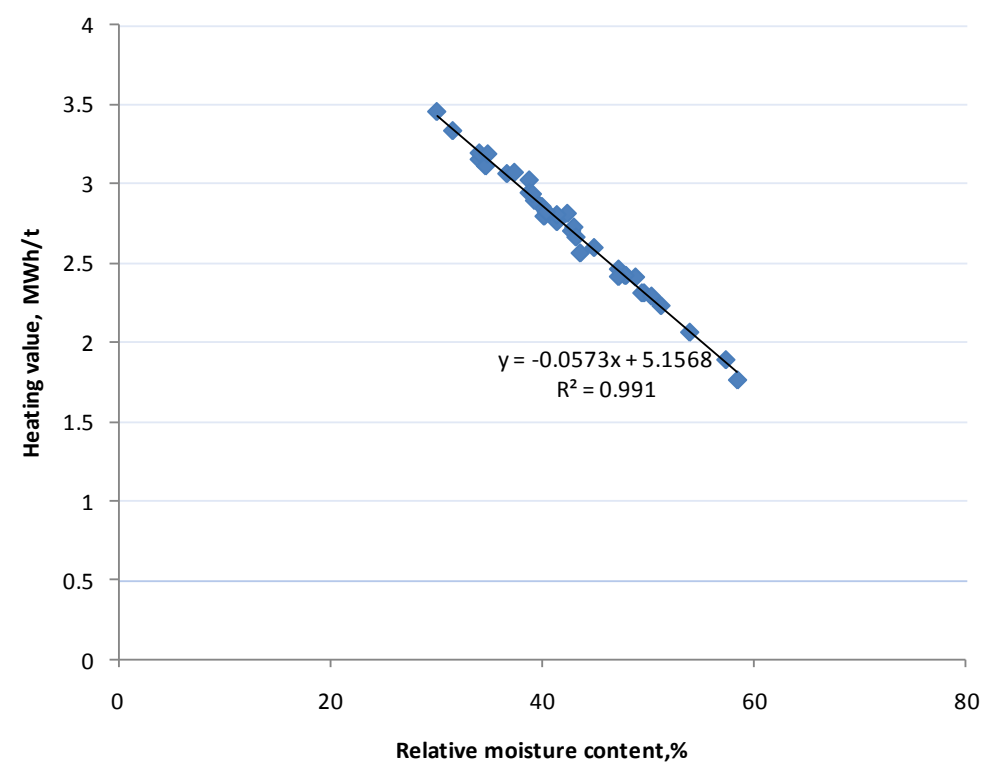

Fig. 11. The diagramm of correlation between the factrorial feature ( relative wood moisture content, \%) and the feature of the result (heating value, $\mathrm{MWh} / \mathrm{t}$ )

7. The heating value changes of energy chips in $2 \%$ cases can be explained by linear model of regression, where the factor $\mathrm{X}-$ ash content, $\%$. The model of regression $\mathrm{Y}=-$ $0.0544 \mathrm{X}+2.9135$ (fig.12.). 


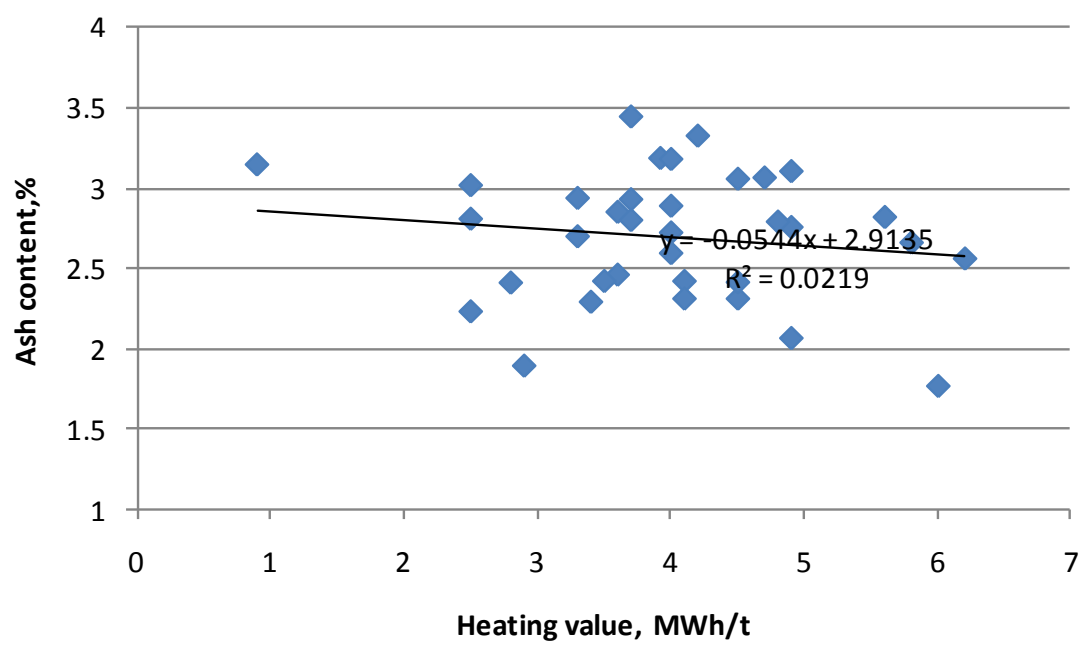

Fig. 12. The diagramm of correlation between the factrorial feature ( ash content $\%$ ) and the feature of the result (heating value, $\mathrm{MWh} / \mathrm{t}$ )

8. The characteristic parameters represented the quality of energy chips manufacured in period 2010-2011 have been determinated (table 1).

Table 1.

The results of the representative parameters of energy chips manufactured in 2010-2011

\begin{tabular}{|c|c|c|c|c|}
\hline Standard & Parameter & Unit & Characteristic value & Variation \\
\hline LVS CEN/TS 15103:2005 & Bulk density & $\mathrm{kg} /$ loose $\mathrm{m}^{3}$ & 320 & $290-440$ \\
\hline LVS CEN/TS 14775:2004 & Ash content, $\mathrm{W}=0 \%$ & $\%$ & 3.8 & $2.9-6.0$ \\
\hline \multirow{3}{*}{ LVS CEN/TS 14918:2005 } & Hydrogen, $W=0 \%$ & $\%$ & 6.1 & \\
\hline & Oxygen, $W=0 \%$ & $\%$ & 41 & \\
\hline & Nitrogen, $\mathrm{W}=0 \%$ & $\%$ & 0.5 & \\
\hline \multirow{6}{*}{ LVS CEN/TS 14918:2005 } & \multirow[b]{2}{*}{ Higher heating value per dry mass } & $\mathrm{MJ} / \mathrm{kg}$ & 20.3 & \\
\hline & & $\mathrm{MWh} / \mathrm{t}$ & 5.61 & $5.52-5.82$ \\
\hline & \multirow[b]{2}{*}{ Lower heating value perdry mass } & $\mathrm{MJ} / \mathrm{kg}$ & 18.7 & \\
\hline & & $\mathrm{MWh} / \mathrm{t}$ & 5.19 & $5.18-5.277$ \\
\hline & & $\mathrm{MJ} / \mathrm{kg}$ & 6.35 & \\
\hline & Lower heating value according to moisure content of the chips & $\mathrm{MWh} / \mathrm{t}$ & 2.394 & 1.763-3.098 \\
\hline LVS CEN/TS 14774-2:2004 & Average relative moisture content & $\%$ & 42 & 30-58.4 \\
\hline
\end{tabular}

\section{Conslussions}

1. The quality parametrs of energy chips could be determined by testing the relative wood moisture content of harvesting residues (fig.13). In this way the storage costs and the impact on environment are decreased, the best solution for optimal technological process of energy chips manufacturing selection operatively could be accepted (fig.3.). 


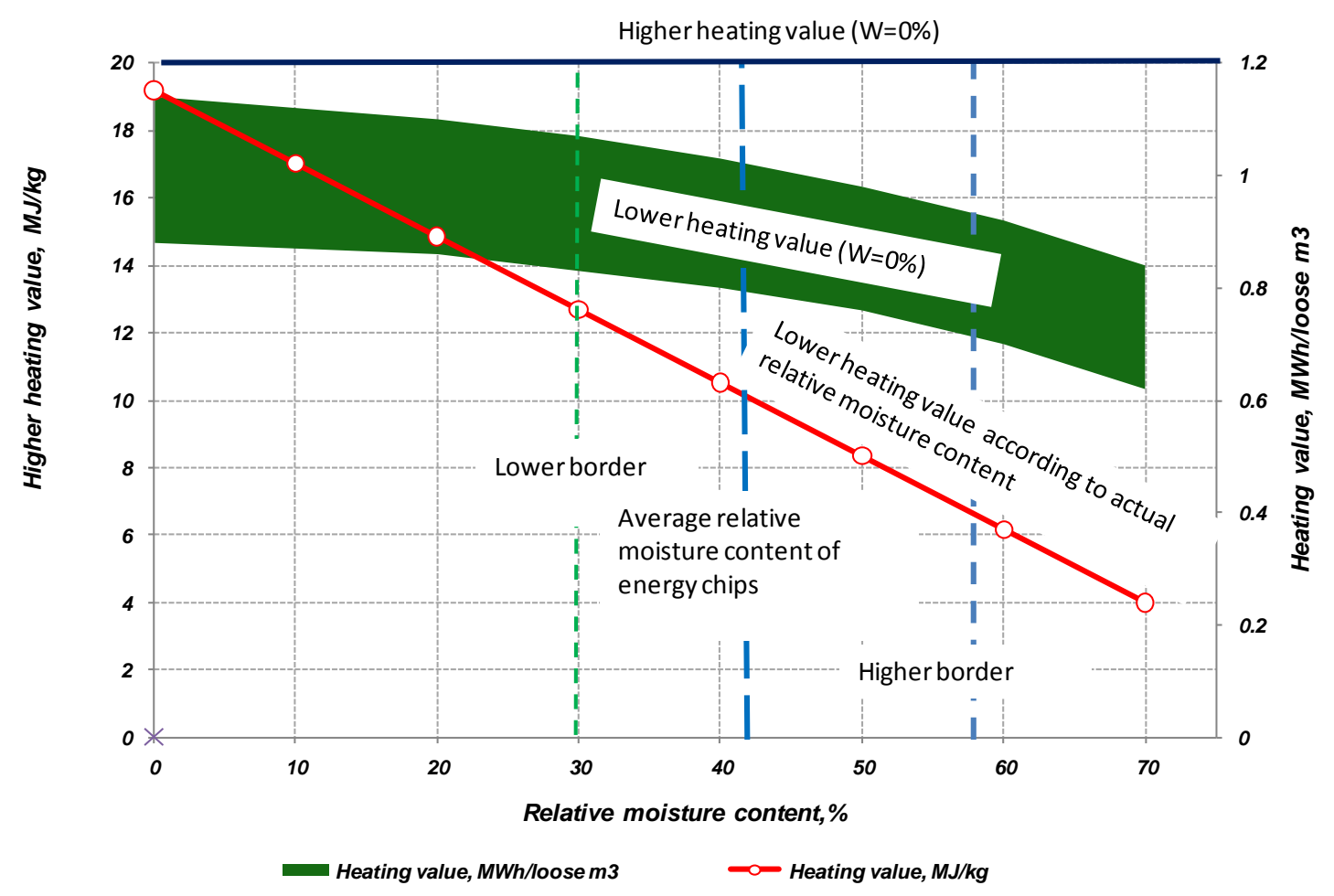

Fig.13. The coherence diagramm between higher heating value and relative wood moisture content of energy chips in 2010 by average bulk density ( $W=0 \%$ ) $420-470$ $\mathrm{kg} / \mathrm{m}^{3}$, average wood moisture content $42 \%$, average ash content 3.8 and coherence 0.36 solid $\mathbf{m}^{3}=1$ loose $\mathbf{m}^{3}$

2. The moisture content of fresh harvesting residues can vary from a minimum $40 \%$ to a maximum of $60 \%$, depending on a number of the main factors, which generally include the species, the season and the tree portion. For example, moisture content of alder harvested in May is 45.6\%, harvested in September - 40.1\% [12]. The best period for chipping is when the wood relative moisture content is $35-40 \%$. If in outumn-winter period it is impossible to ensure storaging of harvesting residues in storage less than 2 weeks, there is the risk that the higher zones of the stock is re-wetted and the relative wood moisture content increases up to $60 \%$. In that case it is advised to choose the technological process (1) (fig.3.).

\section{Summary}

Measurement methods based on the determination of dry weight, heating values and moisture content of energy chips used in long term energy chips storage places (piles in harbour) before selling give the final results characterized the quality of energy chips. By using only that methods, there are not possible to control the whole manufacturing process and to choose the best solution for decrease the risks to lose the quality of assortiment.

Accordingly, it is of great practical importance to establish a simple, effective and inexpensive methodology for determination the predict quality parameters of energy chip in the process of manufacturing..

This research paper focuses on the qualitative properties of energy chips. Energy chips often consists of material from various tree species with different proportions of wood, bark, foliage, twigs, needles, buds and even cones and different moisture content. Only by controlling the quality of energy chips in each phase of manufacturing it is possible to choose the correct technological solution. 


\section{Bibliography}

1. Brandel, G. 1990. Volume functions for individual trees, Swedish University of Agricultural Sciences, Dep. of Forest Yield Research, Report No. 26. (In Swedish; English summary.).

2. Bjorklund, T., Ferm, A. Pienikokoisen koivun ja harmaalepän biomassa ja tekniset ominaisuudet. Abstract: Biomass and technical properties of smallsized birch and grey alder // Folia Forestalia. 1982. № 500. P. 137 .

3. Developing technology for large-scale production of forest chips. Helsinki. Wood Energy Technology Programme 1999-2003. Final report. Tekes. Technology Programme Report 6/2004.pp.53-62

4. Fagernäs, L., McKeough, P. \& Kallio, M. 2004. Puupolttoaineiden esikäsittelyn kemialliset vaikutukset. Projektin loppuraportti

5. Flyktman, M. 2003. Polttoaineen kuivauksen kannattavuus laitoksilla. VTT Prosessit. Projektiraportti $\mathrm{PRO} / \mathrm{T} 6510 / 02$.

6. Hillebrand, K. \& Nurmi, J. 2001. Hakkuutähteiden laadunhallinta. PUUT09. Puuenergian teknologiaohjelman vuosikirja. VTT Symposium 216:285-295

7. Hillebrand, K. \& Nurmi, J. 2004. Energiapuun kuivatus ja varastointi - osaprojekti. Puuenergian teknologiaohjelman vuosikirja. VTT Symposium 231: 53-62.

8. Impola, R. 2001. Mekaanisen metsäteollisuuden sivutuotteiden polttoteknisten ominaisuuksien parantaminen. Osaraportti 2. Kuoren kosteuden alentaminen. VTT Energia. Tutkimusselostus ENE2/T0049/ 2001.

9. Kuoppamäki, R. 2001. Mekaanisen metsäteollisuuden sivutuotteiden polttoteknisten ominaisuuksien parantaminen. Osaraportti 3. Kuoren varastointi. VTT Energia. ENE2/T0019/2001.

10. Koksnes atliekas 2006: LVMI „Silava”. Pārskats par cirsmu atlieku apjoma un kvalitātes novērtěšanu. 2006.

11. Skogforsk\&Silava 2006: T.Magnus, H.von Hofsten, H.Lundstrom, V.Lazdāns, A.Lazdiņš. Ciršanas atlieku kurināmā sagatavošana ar harvesteru izstrādātās kailcirtēs.2006.

12. http:/www. Biomasssaforestate.org/ilvasa/file/indaginesulla cippaturainItalia.pdf..

13. LVS CEN/TS 14778-2:2005 Paraugu ievākšana un sagatavošana.

14. LVS CEN/TS 15103:2005 Bēruma blīvums

15. LVS CEN/TS 14774-2:2004 Mitrums

16. LVS CEN/TS 14918:2004 Siltumspēja

17. LVS CEN/TS 15149-1:2006 Frakciju sastāvs

18. CEN/TS 14588:2003 Solid biofuels - Terminology, definitions and descriptions 